\title{
Effect of essential oils from Mangifera indica $L$. cultivars on the antifungal susceptibility of Candida spp. strains isolated from dogs
}

\author{
Efeito dos óleos essenciais de variedades de "Mangifera indica" L. na susceptibilidade \\ antifúngica de cepas de Candida spp. isoladas de cães
}

FONTENELLE, Raquel Oliveira dos Santos ${ }^{1}$; SOBRINHO, Antonio Carlos Nogueira ${ }^{2 *}$; SOARES, Bruna Vieira ${ }^{3}$; AGUIAR, Francisca Lidiane Linhares de ${ }^{4}$; BRITO, Erika Helena Sales de ${ }^{5}$; CAVALCANTE, Carolina Sidrim de Paula ${ }^{4}$; ROCHA, Marcos Fábio Gadelha $^{3,6}$; MORAIS, Selene Maia de ${ }^{2,3}$.

\footnotetext{
${ }^{1}$ Universidade Estadual Vale do Acaraú, Centro de Ciências Agrárias e Biológicas, Sobral, Ceará, Brasil.

${ }^{2}$ Universidade Estadual do Ceará, Rede Nordeste de Biotecnologia-Renorbio, Programa de PósGraduação em Biotecnologia, Fortaleza, Ceará, Brasil.

${ }^{3}$ Universidade Estadual do Ceará, Faculdade de Veterinária, Programa de Pós-Graduação em Ciências Veterinárias, Fortaleza, Ceará, Brasil.

${ }^{4}$ Universidade Federal do Ceará, Faculdade de Farmácia, Odontologia e Enfermagem, Programa de PósGraduação em Ciências Farmacêuticas, Fortaleza, Ceará, Brasil.

${ }^{5}$ Universidade da Integração Internacional da Lusofonia Afro-Brasileira, Instituto de Ciências da Saúde, Redenção, Ceará, Brasil.

${ }^{6}$ Universidade Federal do Ceará, Centro Especializado em Micologia Médica, Departamento de Patologia e Medicina Legal, Fortaleza, Ceará, Brasil.

*Endereço para correspondência: caiosobrinho@yahoo.com.br
}

\section{RESUMO}

Este trabalho descreve a composição química e a atividade anti-Candida spp. de óleos essenciais de folhas de diversos cultivares de Mangifera indica. Os óleos essenciais foram obtidos por meio de hidrodestilação e analisados por cromatografia de gás acoplada à espectrometria de massa. A atividade antiCandida spp. foi avaliada contra cepas isoladas de cães pelo método de difusão em ágar e a concentração inibitória mínima (CIM) pelo método de microdiluição em caldo. $\mathrm{O}$ cultivar Tommy Atkins apresentou $\beta$-selineno (29.49\%), óxido de cariofileno $(12.40 \%)$ e humuleno II epoxido (8.66\%) como seus constituintes principais, enquanto que os principais componentes das variedades Rosa, Moscatel e Jasmim foram óxido de cariofileno $(23,62,48,42$ e $30,77 \%$, respectivamente) e humuleno II epoxido $(11,56,23,45$ e 16,27\%, respectivamente). As médias de zona de inibição foram $11 \pm 0,71,13,5 \pm 3,54,10,5 \pm$ 0,71 e $13,5 \pm 0,71 \mathrm{~mm}$ respectivamente para os cultivares Tommy Atkins, Rosa, Moscatel e Jasmim. Para a variedade Tommy Atkins, a CIM variou de 0,62 a $1,25 \mathrm{mg} / \mathrm{mL}$; para Rosa, 0.31 a $1.25 \mathrm{mg} / \mathrm{mL}$; para Jasmim os valores variaram de 0,31 a $0,62 \mathrm{mg} / \mathrm{mL}$; ao passo que para a variedade Moscatel o valor de CIM foi $1,25 \mathrm{mg} / \mathrm{mL}$ para todas as cepas de Candida spp. Os óleos essenciais das quatro variedades de $M$. indica foram ativos in vitro contra Candida spp., demonstrando boa atividade antifúngica, podendo ser uma fonte útil de compostos antifúngicos para uso na medicina veterinária.

Palavras-chave: manga, leveduras, óleos aromáticos, óxido de cariofileno, pequenos carnívoros

\section{SUMMARY}

This work reports the chemical study, and antiCandida spp. activity of leaf essential oil from Mangifera indica cultivars. The essential oils were obtained by hydro-distillation and analyzed by gas chromatography/mass spectroscopy. The anti-Candida spp. activity was evaluated against strains isolated from dogs by the agar-well diffusion method and the minimum inhibitory concentration (MIC) by the broth microdilution method. Tommy Atkins 
cultivar presented $\beta$-selinene $(29.49 \%)$, caryophyllene oxide $(12.40 \%)$ and humulene II epoxide $(8.66 \%)$ as main constituents, while the main constituents of Rosa, Moscatel and Jasmim varieties were caryophyllene oxide (23.62, 48.42 and $30.77 \%$, respectively) and humulene epoxide II $(11.56,23.45$, and $16.27 \%$, respectively). The means of inhibition zones were $11 \pm 0.71,13.5 \pm 3.54,10.5 \pm 0.71$ and $13.5 \pm 0.71 \mathrm{~mm}$ to Tommy Atkins, Rosa, Moscatel and Jasmim varieties, respectively. For Tommy Atkins, the MIC ranged from 0.62 to $1.25 \mathrm{mg} / \mathrm{mL}$; for Rosa, ranged from 0.31 to $1.25 \mathrm{mg} / \mathrm{mL}$; for Jasmim ranged from 0.31 to $0.62 \mathrm{mg} / \mathrm{mL}$; while for the Moscatel variety the MIC value was $1.25 \mathrm{mg} / \mathrm{mL}$ for all Candida strains. Essential oils of four $M$. indica cultivars were active in vitro against Candida spp., demonstrating good antifungal activity and can be a useful source of antifungal compounds for veterinary medicine.

Keywords: mango, yeasts, aromatic oils, caryophyllene oxide, small carnivores

\section{INTRODUCTION}

Mangifera indica L. (Sapindales: Anacardiaceae), a medicinal and horticultural plant, is among the most popular and best-known tropical fruits, including many cultivars (JAHURUL et al., 2015). Mango occupies the 2nd position as a tropical crop, behind only bananas in terms of production and acreage used (MUCHIRI et al., 2012). Traditionally, the mango plant has medicinal applications as a febrifuge and to treat diarrhea, dysentery, gastrointestinal tract disorders, typhoid fever, sore throat and scurvy. The mango fruits are source of vitamin A and also can be used in treatment of blood disorders (THOMAS et al., 2015).

Studies have reported the activity of several parts of this species, which include anti-inflammatory (SRAVANI et al., 2015), antioxidant (UMAMAHESH et al., 2016; DAS et al., 2015), antihyperglycemic (AWASTHI et al., 2016), antiulcerogenic (SEVERI et al., 2009), antihypertensive (RONCHI et al.,
2015). The leaf decoction is popularly used as stomachic, anti-diarrheic and against genito-urinary inflammations, bronchitis and asthmas and in external use, in baths or washes against scabies and syphilis (AGRA et al., 2007). Bbosa et al. (2007) reported the antibacterial activity for the leaves and concluded that the use of mango leaf in conjunction with a toothbrush will be a good home care device for maintenance of oral hygiene. The seeds extract demonstrated antibacterial activity that may be due to the presence of tannin and higher amount of total phenol content (VAGHASIYA et al., 2011).

Malassezia sp. and Candida sp. are yeasts commonly found in normal flora from small carnivores, as dogs. Nevertheless, despite being saprobes, there have been many reports of infections caused by these microorganisms (BRITO et al., 2009). Infecction which present different clinical manifestations, such as dermatomycosis (YURAYART et al., 2014), systemic infections (SKORIC et al., 2011), urinary infections (ÁLVAREZ-PÉREZ et al., 2016) and otitis externa (EBANI et al., 2017).

Although effective antimicrobials have been developed over the years, there has been increased development of antimicrobial drug resistance to currently available antimicrobials (SANGUINETTI et al., 2015). Due to many activities of $M$. indica leaves, the essential oils from four cultivars found in Brazil, Tommy Atkins, Rosa, Moscatel and Jasmim, were screened for antimicrobial activity against Candida spp. strains isolated from symptomatic dogs.

\section{MATERIALS AND METHODS}

The leaves of four mango varieties Tomy Atkins, Rosa, Moscatel and Jasmim were collected in the Fortaleza city, State of Ceará situated in northeast 
of Brazil (3'33'46' latitude S, $41^{\circ} 05^{\prime} 42$ ''longitude W). Fresh leaf of mango varieties were subjected to hydrodistillation for $2 \mathrm{~h}$ in a modified Clevenger type apparatus, as described by CRAVEIRO et al. (1976). The oil was dried over anhydrous $\mathrm{Na}_{2} \mathrm{SO}_{4}(\sim 1$ $\mathrm{g}$ ), filtered and preserved in a sealed vial at $4^{\circ} \mathrm{C}$ prior to further analysis, with a yield of $0.85 \%(\mathrm{w} / \mathrm{w})$. All the essential oils were kept in tightly stoppered bottle in a freezer until used for biological tests.

The chemical analysis of the essential oils constituents were performed on a Shimadzu QP-2010 instrument employing the following conditions: column: DB-5ms (Agilent, part No. 1225532) coated fused silica capillary column $(30 \mathrm{~m} \times 0.25 \mathrm{~mm} \times 0.25 \mu \mathrm{m})$; carrier gas: $\mathrm{He}(1 \mathrm{~mL} / \mathrm{min}$, in constant linear velocity mode); injector temperature was $250^{\circ} \mathrm{C}$, in split mode (1:100), and the detector temperature was $250^{\circ} \mathrm{C}$. The column temperature programming was 35 to $180^{\circ} \mathrm{C}$ at $4^{\circ} \mathrm{C} / \mathrm{min}$ then 180 to $280^{\circ} \mathrm{C}$ at $17^{\circ} \mathrm{C} / \mathrm{min}$, and at $280^{\circ} \mathrm{C}$ for $10 \mathrm{~min}$; mass spectra: electron impact $70 \mathrm{eV}$. The injected sample volume was $1 \mu \mathrm{L}$. Compounds were identified by their GC retention times relative to know compounds and by comparison of their mass spectra with those present in the computer data bank (National Institute for Standard Technology - NIST - 147, 198 compounds) and published spectra (ADAMS, 2012; ALENCAR et al., 1984).

A total of three strains of $C$. albicans and two strains of $C$. tropicalis were included in this study. The Candida spp. strains were isolated from the preputial, vaginal, oral and perianal mucosae of healthy dogs. The isolates cultured were identified according to their biochemical profile and morphological characteristics (BRITO et al., 2009). The strains were stored in the fungal collection of the Specialized Medical
Mycology Center - CEMM (Federal University of Ceará, Brazil), where they were maintained in saline $(0.9 \% \mathrm{NaCl})$, at $28^{\circ} \mathrm{C}$. At the time of the analysis, an aliquot of each suspension was taken and inoculated into potato dextrose agar (Difco, Detroit, USA), and then incubated at $28^{\circ} \mathrm{C}$ for $2-10$ days.

For the agar-well diffusion method, based on Fontenelle et al. (2007), stock inocula was prepared on day 2, grown on potato dextrose agar (Difco, Detroit, USA) at $28^{\circ} \mathrm{C}$. Potato dextrose agar was added to the agar slant and the cultures were gently swabbed to dislodge the conidia. The suspension with blastoconidia of Candida spp. was transferred to a sterile tube and adjusted by turbidimetry to obtain inocula of approximately $10^{6} \quad \mathrm{CFU} / \mathrm{mL}$ blastoconidia. The optical densities of the suspensions were spectrophotometrically determined at $530 \mathrm{~nm}$ and then adjusted to $95 \%$ transmittance.

For the broth microdilution method, standardized inocula $\left(2.5-5 \times 10^{3}\right.$ $\mathrm{CFU} / \mathrm{mL}$ for Candida spp.) were also prepared by turbidimetry. Stock inocula was prepared on day 2, grown on potato dextrose agar at $28^{\circ} \mathrm{C}$. Sterile normal saline solution $(0.9 \% ; 3 \mathrm{~mL})$ was added to the agar slant and the culture was gently swabbed to dislodge the conidia from the blastoconidia from Candida spp. (BRITO et al., 2009). The blastoconidia suspension was transferred to a sterile tube, and the volume of suspension adjusted to $4 \mathrm{~mL}$ with sterile saline solution. The resulting suspension was allowed to settle for $5 \mathrm{~min}$ at $28^{\circ} \mathrm{C}$, and the density was read at $530 \mathrm{~nm}$ and the adjusted to $95 \%$ transmittance. The suspension was diluted to 1:2000 with RPMI 1640 medium (Roswell Park Memorial Institute - 1640) with Lglutamine, without sodium bicarbonate (Sigma Chemical Co., St. Louis, Mo.), buffered to $\mathrm{pH} \quad 7.0$ with $0.165 \mathrm{M}$ morpholinepropanesulfonic acid (MOPS) (Sigma Chemical Co., St. Louis, Mo.), to 
obtain the inoculum size of approximately $2.5-5 \times 10^{3} \mathrm{CFU} / \mathrm{mL}$.

The antifungal activity of essential oils was evaluated against Candida spp. by the agar-well diffusion method according to Fontenelle et al. (2007). Petri dishes with $15 \mathrm{~cm}$ diameter were prepared with potato dextrose agar (Difco, Detroit, USA). The wells (6 mm in diameter) were then cut from the agar and $100 \mu \mathrm{L}$ of essential oil was delivered into them. The oils were weighed and prepared in dimethyl sulfoxide (DMSO) to obtain the test concentrations of $10 \mathrm{mg} \cdot \mathrm{mL}^{-1}$. Stock solutions of amphotericin B (0.005 mg.mL ${ }^{-1}$; Sigma Chemical Co., USA) was prepared in distilled water and tested as positive control for Candida spp. Each fungal suspension was inoculated on to the surface of the agar. After incubation, for 3-5 days at $28^{\circ} \mathrm{C}$, all dishes were examined for zones of growth inhibition and the diameters of these zones were measured in millimeters. Each experiment was repeated at least twice. The minimum inhibitory concentration (MIC) for Candida spp. was determined by the broth microdilution method, in accordance to M27-A3 guidelines of Clinical and Laboratory Standards Institute (CLSI, 2008). The minimum fungicidal concentration (MFC) for both Candida spp. were determined according Fontenelle et al. (2007). In addition, $C$. parapsilosis (ATCC 22019) and $C$. albicans (ATCC 1023) strains were used as quality controls for broth microdilution method.

The essential oils of $M$. indica varieties were prepared in mineral oil. Amphotericin B (AMB) (Sigma, Chemical Co., USA) was prepared in DMSO. For the susceptibility analysis, the essential oils samples were tested in concentrations ranging from 0.004 to $5 \mathrm{mg} \cdot \mathrm{mL}^{-1}$. The microdilution assay was performed in 96-well microdilution plates. Growth and sterile control wells were included for each isolate tested. The microplates were incubated at $37^{\circ} \mathrm{C}$ and read visually after 2 days. The assays for all essential oils were run in duplicate and repeated at least twice. The MIC was defined as the lowest oil concentration that caused $100 \%$ inhibition of visible fungal growth. The results were read visually as recommended by CLSI. The MFC was determined by subculturing $100 \mu \mathrm{L}$ of solution from wells without turbidity, on potato dextrose agar, at $28^{\circ} \mathrm{C}$. The MFCs were determined as the lowest concentration resulting in no growth on the subculture after 2 days.

Antifungal activity was expressed as mean \pm SD of the diameter of the growth inhibition zones (mm). The antifungal activity of the essential oils was analyzed by linear correlation for individual analysis and the two-tailed Student's t-test at $95 \%$ confidence intervals was used to evaluate differences between the essential oil and the controls.

\section{RESULTS AND DISCUSSION}

The chemical analyses demonstrated that essential oil from leaves of Tommy Atkins cultivar has $\beta$-selinene (29.49\%), caryophyllene oxide $(12.40 \%)$ and humulene epoxide II $(8.66 \%)$ as main constituents, while the main constituents of Rosa, Moscatel and Jasmim cultivars are caryophyllene oxide (23.62, 48.42 and $30.77 \%$, respectively) and humulene epoxide II (11.56, 23.45, 16.27\%, respectively). The constituents, italicene epoxide, spathulenol, caryophyllene oxide, humulene epoxide II and cyclocolorenone are common to the four essential oils. These results are shown on Table 1. The $M$. indica essential oils are mainly composed of sesquiterpenes. 
Rev. Bras. Saúde Prod. Anim., Salvador, v.18, n.2, p.337-346 abr./jun., 2017

Table 1. Chemical composition of the essential oils from leaves of $M$. indica cultivars

\begin{tabular}{|c|c|c|c|c|c|}
\hline \multirow{2}{*}{ Constituent } & \multicolumn{4}{|c|}{ Composition $(\% *)$} & \multirow[b]{2}{*}{ K.I.** } \\
\hline & Tommy Atkins & Rosa & Moscatel & Jasmim & \\
\hline \multicolumn{6}{|c|}{ Monoterpenoids } \\
\hline$\alpha$-Pinene & - & - & - & 3,13 & 939 \\
\hline $2-\delta$-Carene & - & - & - & 3,31 & 1003 \\
\hline Piperitenone & 1,41 & - & - & 3,17 & 1307 \\
\hline \multicolumn{6}{|c|}{ Sesquiterpenoids } \\
\hline$\alpha$-Copaene & 3,43 & 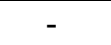 & - & - & 1375 \\
\hline$\beta$-Elemene & 1,45 & 1,30 & - & - & 1391 \\
\hline$\alpha$-Gurjunene & - & 5,64 & - & 4,33 & 1401 \\
\hline Longifolene & 3,52 & - & - & - & 1406 \\
\hline$E$-Caryophyllene & - & 5,40 & - & 4,58 & 1414 \\
\hline Aromadendrene & 1,82 & - & - & - & 1437 \\
\hline$\alpha$-Humulene & - & 4,95 & 2,68 & 4,74 & 1450 \\
\hline Allo-aromadendrene & 3,71 & 2,84 & - & - & 1459 \\
\hline Drima-7,9(11)-diene & 2,49 & - & - & - & 1469 \\
\hline$\beta$-Selinene & 29,49 & - & - & 2,3 & 1483 \\
\hline Viridiflorene & - & 2,06 & - & 2,2 & 1485 \\
\hline Valencene & 1,15 & - & & - & 1492 \\
\hline Trans-cycloisolongifolol-5-ol & - & 2,11 & - & - & 1512 \\
\hline Silfiperfol-5-en-3-ol-B & - & 3,64 & - & - & 1529 \\
\hline Eremophila ketone & 1,44 & - & - & - & 1534 \\
\hline Italicene epoxide & 7,81 & 2,56 & 4,42 & 3,32 & 1551 \\
\hline$\beta$-Germacrene & 1,02 & - & - & 1,19 & 1562 \\
\hline Espathulenol & 1,93 & 4,32 & 9,19 & 5,81 & 1577 \\
\hline Caryophyllene oxide & 12,40 & 23,62 & 48,42 & 30,77 & 1583 \\
\hline Viridiflorol & 1,77 & - & - & - & 1604 \\
\hline Humulene epoxide II & 8,66 & 11,56 & 23,45 & 16,27 & 1610 \\
\hline Eudesmol(10-epi-gamma) & - & - & - & 4,37 & 1624 \\
\hline Allo-aromadendrene epoxide & 2,85 & - & - & - & 1630 \\
\hline Xanthoirhizol & 1,40 & - & - & - & 1748 \\
\hline Ciclocolorenone & 7,26 & 5,91 & 4,55 & 2,68 & 1757 \\
\hline Aristolone & 1,58 & - & - & - & 1761 \\
\hline \multicolumn{6}{|c|}{ Methylated fatty acid } \\
\hline Methyl linoleate & - & 3,04 & 2,26 & - & 2092 \\
\hline Total (Contet \%) & 96,59 & 78,99 & 94,27 & 92,17 & - \\
\hline
\end{tabular}

Plant essential oils are a potentially useful source of antimicrobial compounds, and important in the development of new drugs due to have served as models for the synthesis of drugs with diverse pharmacological properties and chemical structures (SOBRINHO et al., 2016). It is often quite difficult to compare the results obtained from different studies, because the compositions of the essential oils can vary greatly depending upon the geographical region, the variety, the age of the plant, the method of drying and the extraction method (FIGUEIREDO et al., 2008). Several previous studies have demonstrated the activity of essential oils isolated from Brazilian biomes plants against Candida species (DUARTE et al. 2005). Previous study described anti-Candida activity against Lippia sidoides Cham. (FONTENELLE et al., 2007) and Croton species (FONTENELLE et al., 2008), Brazilian Northeast plants with ethnomedicinal and bioactive properties. 
However, there is no specific study of the anti-Candida activity of essential oils from leaves of $M$. indica varieties. The antifungal activity of the essential oils was initially tested by the agar-well diffusion assay, at the $10 \mathrm{mg} / \mathrm{mL}$ concentration, against 2 strains of Candida spp. isolated from symptomatic dogs. All of then induced growth inhibition zone, these results are shown in Table 2. The means inhibition zones were $11 \pm 0.71,13.5 \pm 3.54,10.5$ \pm 0.71 and $13.5 \pm 0.71 \mathrm{~mm}$ to Tommy Atkins, Rosa, Moscatel and Jasmim cultivars, respectively. The positive control amphotericin B induced a significant growth inhibition zone of 9.5 $\pm 0.71 \mathrm{~mm}$.
Based on this initially screen, all of mango essential oils were submitted to the broth microdilution method (Table $3)$ for Candida spp. strains $(n=5)$. For Tommy Atkins, the MIC ranged from 0.62 to $1.25 \mathrm{mg} / \mathrm{mL}$ and the geometric mean was $0.87 \mathrm{mg} / \mathrm{mL}$; for Rosa, ranged from 0.31 to $1.25 \mathrm{mg} / \mathrm{mL}$ and the geometric mean was $0.68 \mathrm{mg} / \mathrm{mL}$; for Jasmim ranged from 0.31 to 0.62 $\mathrm{mg} / \mathrm{mL}$ and the geometric mean was $0.49 \mathrm{mg} / \mathrm{mL}$; and for Moscatel, the MIC value was the same for all strains of Candida spp. The most effective variety was Jasmim, following by Rosa, Tommy Atkins and Moscatel.

Table 2. Antifungal activity of the essential oils of $M$. indica varieties against Candida spp. in the agar-well diffusion assay

\begin{tabular}{|c|c|c|c|c|c|}
\hline \multirow[b]{2}{*}{ Strains } & \multicolumn{5}{|c|}{ Growth inhibition zones (mm) } \\
\hline & $\begin{array}{c}\text { Tommy Atkins } \\
10 \mathrm{mg} / \mathrm{mL}\end{array}$ & $\begin{array}{c}\text { Rosa } \\
10 \mathrm{mg} / \mathrm{mL}\end{array}$ & $\begin{array}{l}\text { Moscatel } \\
10 \mathrm{mg} / \mathrm{mL} \\
\end{array}$ & $\begin{array}{c}\text { Jasmim } \\
10 \mathrm{mg} / \mathrm{mL} \\
\end{array}$ & $\begin{array}{c}\text { Amphotericin B } \\
0.005 \mathrm{mg} / \mathrm{mL}\end{array}$ \\
\hline \multicolumn{6}{|l|}{ Candida spp. } \\
\hline $\begin{array}{l}\text { CEMM 01-2-078 } \\
\text { (C. tropicalis) }\end{array}$ & 10 & 16 & 10 & 13 & 10 \\
\hline $\begin{array}{l}\text { CEMM 01-2-081 } \\
\text { (C. tropicalis) }\end{array}$ & 12 & 11 & 11 & 14 & 09 \\
\hline$($ mean $\pm \mathrm{SD})$ & $(11 \pm 0.71)$ & $(13.5 \pm 3.54)$ & $(10.5 \pm 0.71)$ & $(13.5 \pm 0.71)$ & $(9.5 \pm 0.71)$ \\
\hline
\end{tabular}

Each experiment was performed in duplicate

Table 3. Minimum inhibitory concentrations of varieties of $M$. indica essential oils against Candida spp.

\begin{tabular}{lcccc}
\hline \multirow{2}{*}{ Strains } & \multicolumn{4}{c}{ M. indica essential oils } \\
\cline { 2 - 5 } & Tommy Atkins & Rosa & Moscatel & Jasmim \\
\cline { 2 - 5 } & MIC $(\mathrm{mg} / \mathrm{mL})$ & MIC $(\mathrm{mg} / \mathrm{mL})$ & MIC $(\mathrm{mg} / \mathrm{mL})$ & MIC $(\mathrm{mg} / \mathrm{mL})$ \\
\hline $\begin{array}{l}\text { Candida } \text { spp. } \\
\text { CEMM 01-3-068 }\end{array}$ & 0.62 & 0.62 & 1.25 & 0.62 \\
$\begin{array}{l}\text { C. albicans) } \\
\text { CEMM 01-3-069 }\end{array}$ & 1.25 & 0.62 & 1.25 & 0.62 \\
$\begin{array}{l}\text { C. albicans) } \\
\text { CEMM 01-3-077 }\end{array}$ & 1.25 & 0.62 & 1.25 & 0.62 \\
$\begin{array}{l}\text { C. albicans) } \\
\text { CEMM 01-2-078 }\end{array}$ & 0.62 & 0.31 & 1.25 & 0.31 \\
$\begin{array}{l}\text { (C. tropicalis) } \\
\text { CEMM 01-2-081 }\end{array}$ & 0.62 & 1.25 & 1.25 & 0.31 \\
$\begin{array}{l}\text { C. tropicalis) } \\
\text { (Geometric mean) }\end{array}$ & 0.87 & 0.68 & 1.25 & 0.49 \\
\hline
\end{tabular}

MIC $=$ minimum inhibitory concentration expressed in $\mathrm{mg} / \mathrm{mL} ;$ CEMM $=$ specialized Medical Mycology Center. Each experiment was repeated at least twice. 
The constituents $\alpha$-pinene and $2-\delta$-carene, found just in Jasmim variety, have antibacterial against many bacterial strains reported by Dorman \& Deans (2000). The $\alpha$-pinene is a compound of Mentha arvensis var. piperita $\mathrm{L}$. essential oil, and Duarte et al (2005) shown a MIC value of $1.1 \mathrm{mg} / \mathrm{mL}$ against $C$. albicans for this oil. These antimicrobial compounds may have increased the antifungal activity of Jasmim essential oil. Therefore, the high content of sesquiterpenes in both mango essential oils may be a factor that influences the antimicrobial activity observed. Caryophyllene oxide, main constituent from essential oils, showed antifungal activity against $C$. albicans by broth microdilution method (SKALTSA et al., 2003).

Probably there is a correlation between the antifungal activity of the studied oils and their main constituents. Corroborating this hypothesis, previous studies have demonstrated that the essential oils in which spathulenol and caryophyllene oxide are the main compounds have inhibitory activity on filamentous fungi species (FARAG et al., 2004; WENQIANG et al., 2006). These compounds must have inhibitory activity against Candida species too, because are abundant in all essential oils tested in this study. These results are important because strains of Candida spp. isolated from dogs showed high resistance to azole antifungal agents (BRITO et al., 2009).

The results of the present study indicate that the essential oils obtained from leaves of $M$. indica cultivars found in Brazil showed antifungal activity against Candida spp. strains. These results corroborate the importance of ethnopharmacological surveys in the selection of plants for bioactivity screening. The results contribute to the characterization of the anti-Candida activity of essential oils and plant extracts of traditional medicinal plants from the Brazilian flora. Subsequently, bio- guided fractionation will be conducted on plants showing potential antiCandida activity to identify the active compounds. Evaluations of the toxicological aspects and antimicrobial activity against other important human and especially animal pathogens are also being conducted.

\section{ACKNOWLEDGEMENTS}

The authors are indebted to the Laboratory of Natural Products Chemistry of State University of Ceará, the Microbiology Laboratory of State University of Vale do Acaraú, and the financial support of FUNCAP and CNPq/UNIVERSAL (No. 447291/2014-9).

\section{REFERENCES}

\author{
ADAMS, R.P. Identification of \\ essential oils by ion trap mass \\ spectroscopy. USA: Allured Publishing \\ Corporation, 2012.
}

AGRA, M.F.; FREITAS, P.F.; BARBOSA-FILHO, J.M. Synopsis of the plants known as medicinal and poisonous in Northeast of Brazil.

Revista Brasileira de Farmacognosia, v.17, n.1, p.114-140, 2007.

ALENCAR, W.J.; CRAVEIRO, A.A.; MATOS, F.J.A. Kovats' indices as a preselection routine in mass spectra library searches of volatiles. Journal of Natural Products, v.47, n.5, p.890892, 1984.

ÁLVAREZ-PÉREZ, S.; GARCÍA, M.E.; CUTULI, M.T.; FERMÍN, M.L.; DAZA, M.Á.; PELÁEZ, T.; BLANCO, J.L. Acquired multi-azole resistance in Candida tropicalis during persistent urinary tract infection in a dog. Medical mycology case reports, v.11, p.9-12, 2016. 
AWASTHI, A.; PARWEEN, N.;

SINGH, V.K.; ANWAR, A.; PRASAD, B.; KUMAR, J. Diabetes: Symptoms,

Cause and Potential Natural Therapeutic Methods. Advances in Diabetes and

Metabolism, v.4, n.1, p.10-23, 2016.

BBOSA, G.S.; KYEGOMBE, D.B.; OGWAL-OKENG, J.; BUKENYAZIRABA, R.; ODYEK, O.; WAAKO, $\mathrm{P}$. Antibacterial activity of Mangifera indica (L.). African Journal of Ecology, v.45, n.s1, p.13-16, 2007.

BRITO, E.H.S.; FONTENELLE, R.O.S.; BRILHANTE, R.S.N.; CORDEIRO, R.A.; MONTEIRO, A.J.; SIDRIM, J.J.C.; ROCHA, M.F.G. The anatomical distribution and antimicrobial susceptibility of yeast species isolated from healthy dogs. The Veterinary Journal, v.182, n.2, p.320326, 2009.

CRAVEIRO, A.A.; MATOS, F.J.A.; ALENCAR, J.W. A simple and inexpensive steam generator for essential oils extraction. Journal of Chemical Education, v.53, n.10, p.652, 1976.

DAS, S.; ALAM, M.N.; BATUTA, S.; ROY, N.; BEGUM, N.A. Exploring Comparative Antioxidant Activity of Some Popular Cultivars of Mangifera indica L., National Fruit of India. International Journal of Fruit Science, v.15, n.2, p.129-147, 2015.

DORMAN, H.; DEANS, S.

Antimicrobial agents from plants: antibacterial activity of plant volatile oils. Journal of Applied Microbiology, v.88, n.2, p.308-316, 2000.

DUARTE, M.C.T.; FIGUEIRA, G.M.; SARTORATTO, A.; REHDER, V.L.G.; DELAMERLINA, C. Anti-Candida activity of Brazilian medicinal plants. Journal of Ethnopharmacology, v.97, n.2, p.305-311, 2005.
EBANI, V.V.; NARDONI, S.; BERTELLONI, F.; NAJAR, B.; PISTELLI, L.; MANCIANTI, F. Antibacterial and Antifungal Activity of Essential Oils against Pathogens Responsible for Otitis Externa in Dogs and Cats. Medicines, v.4, n.2, p.21, 2017.

FARAG, R.S.; SHALABY, A.S.; ELBAROTY, G.A.; IBRAHIM, N.A.; ALI, M.A.; HASSAN, E.M. Chemical and biological evaluation of the essential oils of different Melaleuca species. Phytotherapy Research, v.18, n. 1, p.30-35, 2004.

FIGUEIREDO, A.C.; BARROSO, J.G.; PEDRO, L.G.; SCHEFFER, J.J. Factors affecting secondary metabolite production in plants: volatile components and essential oils. Flavour and Fragrance Journal, v.23, n.4, p.213-226, 2008.

FONTENELLE, R.O.S.; MORAIS, S.M.; BRITO, E.H.S.; KERNTOPF, M.R.; BRILHANTE, R.S.N.; CORDEIRO, R.A.; TOMÉ, A.R.; QUEIROZ, M.G.R.; NASCIMENTO, N.R.F.; SIDRIM, J.J.C.; ROCHA, M.F.G. Chemical composition, toxicological aspects and antifungal activity of essential oil from Lippia sidoides Cham. Journal of Antimicrobial Chemotherapy, v.59, n.5, p.934-940, 2007.

FONTENELLE, R.O.S.; MORAIS, S.M.; BRITO, E.H.S.; BRILHANTE, R.S.N.; CORDEIRO, R.A.; NASCIMENTO, N.R.F.; KENTOPF, M.R.; SIDRIM, J.J.C.; ROCHA, M.F.G. Antifungal activity of essential oils of Croton species from the Brazilian Caatinga biome. Journal of Applied Microbiology, v.104, n.5, p.1383-1390, 2008.

JAHURUL, M.; ZAIDUL, I.; GHAFOOR, K.; AL-JUHAIMI, F.; 
NYAM, K.; NORULAINI, N.; SAHENA, F.; OMAR, A. Mango (Mangifera indica L.) by-products and their valuable components: A review. Food Chemistry, v.183, p.173-180, 2015.

MUCHIRI, D.R.; MAHUNGU, S.M.; GITUANJA, S.N. Studies on mango (Mangifera indica, L.) kernel fat of some Kenyan varieties in Meru.

Journal of the American Oil Chemists' Society, v.89, n.9, p.15671575, 2012.

JACRONCHI, S.N.; BRASIL, G.A.; NASCIMENTO, A.M.; LIMA, E.M.; SCHERER, R.; COSTA, H.B.; ROMÃO, W.; BOËCHAT, G.A.P.; LENZ, D.; FRONZA, M.; BISSOLI, N.S.; ENDRINGER, D.C.; ANDRADE, T.U. Phytochemical and in vitro and in vivo biological investigation on the antihypertensive activity of mango leaves (Mangifera indica L.).

Therapeutic Advances in Cardiovascular Disease, v.9, n.5, p.244-256, 2015.

SANGUINETTI, M.; POSTERARO, B.; LASS-FLÖRL, C. Antifungal drug resistance among Candida species: mechanisms and clinical impact. Mycoses, v.58, n.S2, p.2-13, 2015.

SEVERI, J.A.; LIMA, Z.P.; KUSHIMA, H.; BRITO, A.R.M.S.; SANTOS, L.C.; VILEGAS, W.; HIRUMA-LIMA, C.A. Polyphenols with antiulcerogenic action from aqueous decoction of mango leaves (Mangifera indica L.). Molecules, v.14, n.3, p.1098-1110, 2009.

SKALTSA, H.D.; DEMETZOS, C.; LAZARI, D.; SOKOVIC, M. Essential oil analysis and antimicrobial activity of eight Stachys species from Greece.

Phytochemistry, v.64, n.3, p.743-752, 2003.
SKORIC, M.; FICTUM, P.; SLANA, I.; KRIZ, P.; PAVLIK, I. A case of systemic mycosis in a Hovawart dog due to Candida albicans. Veterinarni Medicina, v.56, n.5, p.260-264, 2011.

SOBRINHO, A.C.N.; SOUZA, E.B.; ROCHA, M.F.G.; ALBUQUERQUE, M.R.J.R.; BANDERA, P.N.; SANTOS, H.S.; CAVALCANTE, C.S.P.; OLIVEIRA, S.S.; ARAGÃO, P.R.; MORAIS, S.M.; FONTENELLE, R.O.S. Chemical composition, antioxidant, antifungal and hemolytic activities of essential oil from Baccharis trinervis (Lam.) Pers.(Asteraceae).

Industrial Crops and Products, v.84, p.108-115, 2016.

SRAVANI, D.; AARATHI, K.; KUMAR, N.S.; KRUPANIDHI, S.; RAMU, D.V.; VENKATESWARLU, T.C. In Vitro Anti-Inflammatory Activity of Mangifera indica and Manilkara zapota Leaf Extract.

Research Journal of Pharmacy and Technology, v.8, n.11, p.1477-1480, 2015.

THOMAS, B.T.; OLANPELEKE, A.A.; LAKUNLE, O.M.; DAVIES, A. Mangifera indica crude leaf extracts inhibits efflux pump system in Serratia marscencens. Global Journal of Pharmacology, v.9, p.196-202, 2015.

UMAMAHESH, K.; SIVUDU, S.N.; REDDY, O.V.S. Evaluation of antioxidant activity, total phenolics and total flavonoids in peels of five cultivars of mango (Mangifera indica) fruit.

Food Chemistry, v.4, n.42, p.200-203, 2016.

VAGHASIYA, Y.; PATEL, H.; CHANDA, S. Antibacterial activity of Mangifera indica L. seeds against some human pathogenic bacterial strains.

African Journal of Biotechnology, v.10, n.70, p.15788-15794, 2011. 
WENQIANG, G.; SHUFEN, L.; RUIXIANG, Y.; YANFENG, H. Comparison of composition and antifungal activity of Artemisia argyi Levl. et Vant inflorescence essential oil extracted by hydrodistillation and supercritical carbon dioxide. Natural Product Research, v.20, n.11, p.992998, 2006.

YURAYART, C.; NUCHNOUL, N.; MOOLKUM, P.; JIRASUKSIRI, S.; NIYOMTHAM, W.; CHINDAMPORN, A.; KAJIWARA, S.; PRAPASARAKUL, N. Antifungal agent susceptibilities and interpretation of Malassezia pachydermatis and Candida parapsilosis isolated from dogs with and without seborrheic dermatitis skin. Medical mycology, v.51, n.7, p.721-730, 2013.

Data de recebimento: 09/03/2017

Data de aprovação: 29/05/2017 